the British women's movement among others in western Europe - is now giving more serious consideration to 'entering the main-stream' and making more formal interventions in politics. There are indications - in Norway and West Germany, for example - that this is beginning to produce results.
Women and European Politics provides useful material in an accessible form. The bibliography is a resource in itself, since it lists virtually everything published (in English) on the theory of women's politics and its practice in the European arena.

\section{Catherine Hoskyns}

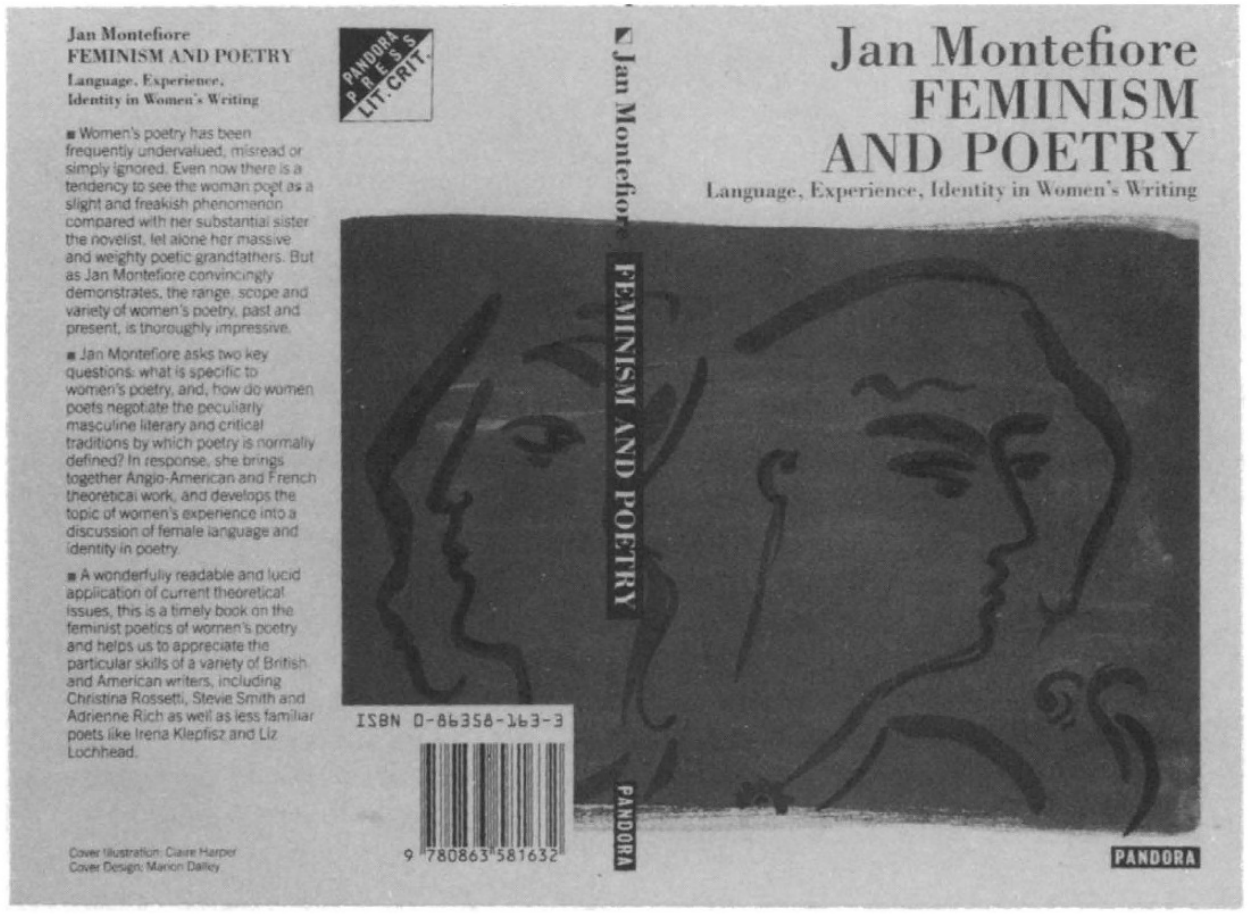

\section{Feminist Criticism: Women as Contemporary Critics Maggie Humm}

Harvester Press Brighton, 1986 ISBN $0710810482 £ 18.95 \mathrm{Hbk}$ ISBN $0710811241 £ 7.95$ Pbk

\section{Feminism and Poetry: Language, Experience and Identity in Women's Writing Jan Montefiore}

Pandora Press London, 1987 ISBN $0863581633 £ 4.95 \mathrm{Pbk}$

\section{Communities of Women:} An Idea in Fiction

Nina Auerbach

Harvard University Press Cambridge, Mass. and London, 1978 ISBN $0674151682 £ 6.75 \mathrm{Pbk}$

If feminist criticism as we know and love it was born in the early 1970 s, it is perhaps not surprising that it should presently, in its adolescent years, be going through something of an identity crisis. One could certainly get that impression from Maggie Humm's Feminist Criticism: Women as Contemporary Critics, a welcome if 
controversial contribution to the small body of introductory texts that now exists. Its subject matter and intended readership invite comparisons with Toril Moi's Sexual/Textual Politics; its hidden agenda (for unlike Moi, Humm never states what her critical position is) does not.

Feminist Criticism is a wideranging book. In Part I, Humm discusses the contributions of pioneers, Millett and De Beauvoir as ever among them, and she gives a survey of the main critical approaches: language and psychoanalysis, Marxistfeminist criticism, myth criticism and Black and lesbian criticism. The latter two chapters give interesting accounts of the suppressed discourses in Sexual/Textual Politics. The section on Black and lesbian criticism (and its overlaps) is especially important given the colourblankness, at best, that mars so much of white feminist criticism. Unfortunately this chapter does not quite fulfil the expectation, raised in the Preface, of making an argument for the centrality of Black and lesbian criticism because of the challenges it poses to critical precepts taken for granted elsewhere.

Part II then consists of more indepth studies of Virginia Woolf, Rebecca West and Adrienne Rich as feminist critics. Here both Woolf and West are read as radical feminists avant la lettre, a mini-tradition of individual struggles with critical fathers and father-figures which, Humm would have us believe, inevitably culminated in Rich's transcendence: woman-identified criticism. This is, to say the least, controversial. Pluralism, says Humm, can replace the normalism (normalism?) of masculine critical traditions. Yet Feminist Criticism often gives the impression that feminist criticism is more Rich than varied, and this is what constitutes its hidden agenda.

More worrying still is the suggestion that because of the multiplicity of techniques and ideas employed by feminist critics whom
Humm wants to celebrate, feminist criticism is perhaps 'the only literary criticism needed by women students' and its language ideally one of emotion and caring'. What we have here is feminist criticism and education as a separatist practice, pretending that a rejection by the adolescent daughter of her critical dad will actually make him go away and erase his internalized authority (for there is that, too).

Jan Montefiore's engagement with the question of women's relation to a largely masculine-defined tradition in Feminism and Poetry: Language, Experience and Identity in Women's Writing provides a rather more subtle, considered and potentially fruitful agenda for feminist criticism. 'The tradition originated and dominated by men, with which women's poetry engages, is itself the site of intense intellectual and political struggle. To ignore this tradition' (or imagine that one can transcend it in one utopian leap) 'means also ignoring women's struggle to transform its values.' Transformation, not rejection, is at the centre of Montefiore's argument. She sets out to answer two crucial questions with regard to women's poetry (with a wider application to women's writing in general): what is specific to women's poetry, and how do women poets engage with masculine discourses by which poetry is normally defined? The ultimate answer to both is women's struggle to transform inherited meanings of a world 'which is dominated by class and race oppression, and by masculine privilege which does not only exert its power at the level of representation.' It is this connexion between women's cultural practices (including criticism) and a wider feminist politics which is crucially absent from Feminist Criticism, thereby providing feminist criticism with a false identity based on no more than ideology critiques and Humm's minimal condition that feminist critics 'must be women choosing to read women as women'. 
For Montefiore this general statement about contestation and transformation of inherited meanings is only a beginning. One reason why Feminism and Poetry is an important and valuable study is that Montefiore in her readings of a variety of women's poems actually demonstrates how particular poets negotiate their relation to poetic tradition in differing ways. Another is the dearth of feminist poetry criticism in this country, especially as compared to the United States and in contrast with the proliferating critical work on women novelists. And finally Montefiore manages to address in an accessible way such difficult problems as the notion of an authenticating female experience, of women's language and identity and the possibility (or not) of a truly feminine textual erotics, still giving complexity its due and never losing sight of her argument.

After Humm's recalcitrant search for a pluralist identity in feminist criticism and Montefiore's transforming struggle with the intricacies of women's poetry, Nina Auerbach's Communities of Women: An Idea in Fiction reads like the pre-feminist scholarly exercise its tentative title suggests. Auerbach's stated aim is to make a case for a tradition of communities of women as a recurrent literary image, 'a rebuke to the conventional idea of a solitary woman living for and through men'. But an idea in fiction it remains. Auerbach's reading-with-the-grain of such a haphazard collection of novels as Pride and Prejudice, Little Women, The Bostonians and The Prime of Miss Jean Brodie fails to be convincing, even if taken by themselves her observations are often interesting. That failure is partly due to the fact that we are never quite sure what we are supposed to be convinced of, since Auerbach's definition of a community of women can range from the unfortunately-thrown-together Bennett sisters to Les Guerillières and back again. It is, to be fairer, probably also because Communities of Women was first published in the US in 1978 , and that is a long time ago in the life of feminist criticism. An apter title for such a project now might be The Girl Gang, identity-crisis, squabbles and fights with parental figures and all.

\section{Maria Lauret}

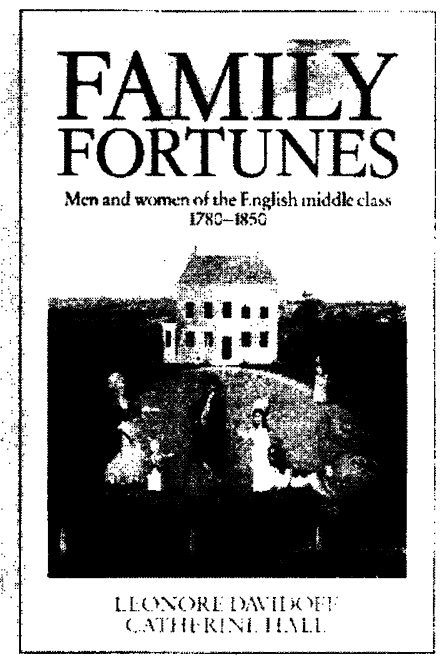

\section{Family Fortunes: Men and Women of the English Middle Class 1780-1850 \\ Leonore Davidoff and Catherine Hall \\ Hutchinson London, 1987 \\ ISBN $0091647002 \mathrm{Hbk} £ 25.00$ \\ ISBN 0091647012 Pbk $£ 10.95$}

One of the more persistent problems of feminist scholarship is the question of how this work may be integrated into those existing forms of analysis which we would want to retain. Inasmuch as gender divisions are not the sole, or even necessarily the primary, structuring features of society, it is essential to examine their interrelations with axes of class, nationality, religion and other social 